\title{
Relationship between the Service Sector and Economic Growth: Evidence from China
}

\section{Vusal Murselzade ${ }^{1}$ Behiye Cavusoglu}

${ }_{1,2}^{2}$ Department of Economics, Near East University, North Cyprus. Email:vusal.murselzade@gmail.com Tel:+994506261402

•Email:behive.cavusoglu@neu.edu.trTel:+905428531911

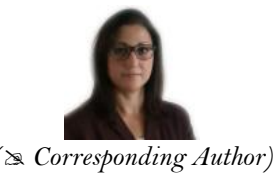

Abstract

The rapid economic growth of China during the last four decades has reshaped the political and economic arena around the world. Under the leadership of Deng Xiaoping, China has realized sets of reforms towards modernization and opening the economy since 1978 and these reforms have helped China to become an economic giant. China's economy is still growing today and a distinct growth pattern together with a complex economic system and the society of China draw interest from all over the world to research and understand what factors trigger such fast growth rates. In this study, the relationship between economic growth and two subsectors of the service sector, namely real estate and hotel \& catering in China, is analyzed. The study uses quantitative methodology and time-series data acquired from secondary sources. The Autoregressive Distributed Lag Method (ARDL) in E-views 10 statistical software is utilized to analyze the data. The findings of the data analysis reveal that both sub sectors have a significant and positive impact on economic growth of China in both the long run and short run. The findings can be generalized and referred to the entire service sector and it can also be claimed that a positive relationship exists between the service sector and economic growth in China.

Keywords: Economic growth, Service sector, Real estate, Hotel, Catering, ARDL, China.

JEL Classification: B40, C10, C13, C19, L89.

Citation I Vusal Murselzade; Behiye Cavusoglu (2021). Relationship between the Service Sector and Economic Growth: Evidence from China. Asian Journal of Social Sciences and Management Studies, 8(1): 15-22.

History:

Received: 18 January 2021

Revised: 22 February 202

Revised: 22 February 202

Accepted: 10 March 2021

Published: 29 March 2021

Licensed: This work is licensed under a Creative Commons Attribution 3.0 License (oc))

Publisher: Asian Online Journal Publishing Group
Acknowledgement: Both authors contributed to the conception and design of the study.

Funding: This study received no specific financial support.

Competing Interests: The authors declare that they have no conflict of interests.

Transparency: The authors confirm that the manuscript is an honest, accurate, and transparent account of the study was reported; that no vital features of the study have been omitted; and that any discrepancies from the study as planned have been explained.

study as planned have been explained.
Ethical: This study follows all ethical practices during writing.

\section{Contents}

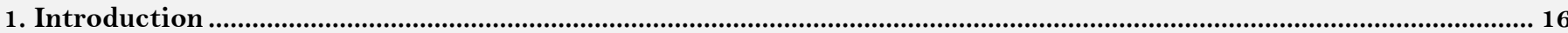

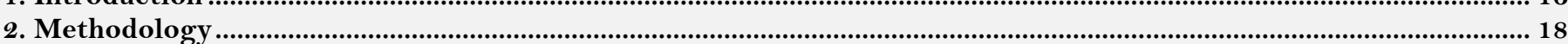

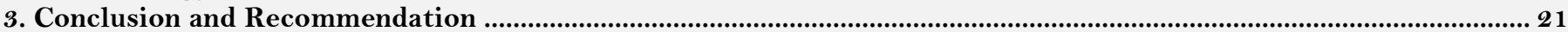

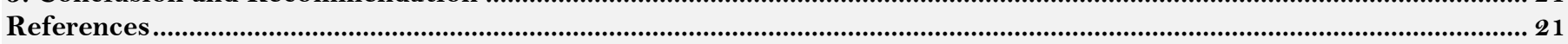




\section{Contribution of this paper to the literature}

This paper contributes to the existing literature on how real estate and hotel \& catering sub sectors affect economic growth in China.

\section{Introduction}

The 20th century witnessed great changes in the geopolitical arena. Events like World Wars, the Great Depression, replacement of hegemonic powers and the Cold War significantly changed and restructured the balance of power among states, causing some of them to become much stronger than before and others to end their existence. The balance of power among world actors is rather a political term, but it has paramount implications for economies. Today, one of the prominent figures in the global geopolitical arena is China. China has realized miracles in the last few decades and achieved significant economic growth, which has significantly improved its status and power among other states. The economic growth of China is perceived differently by regional and global actors. Some of them consider China as a threat, despite China's attempts to build peaceful and beneficial relations with its neighbors and other world actors. Others consider China's economic growth to be an exaggeration, accusing China of falsifying statistical data covering many fields of the Chinese economy. Nevertheless, China's skyrocketing economic growth is an extraordinary phenomenon and a very interesting case for scholars. Numerable scholars have attempted to explore the determinants of Chinese economic growth thus far. In this study, quantitative analysis will be conducted to understand the role of the service sector (two sub sectors of the service sector - real estate and hotel \& catering will be analyzed) in the economic growth of China. This study is a valuable source for all those who are surprised by the economic achievements of China and will help academics to look at growth phenomena from a different and more accurate angle. The study seeks to find answers to the following questions: Is there any relationship between the service sector and economic growth in China in the long run and in the short run? How do the sub sectors of the service sector, namely the real estate and hotel and catering subsectors, impact economic growth in the long run and short run? The main aim of the study is to examine the relationship between the service sector growth and overall economic growth of China.

\subsection{Economic Growth}

Different scholars have defined economic growth in different ways. Howitt. and Weil (2010) interpreted the term as an increase in a country's living standards. Economic growth is generally measured by Gross Domestic Production (GDP) per capita change. Growth can be extensive or intensive. Extensive growth occurs when an increase in the GDP is fully absorbed by population increase, leaving no room for per capita income to rise. Intensive growth happens when the GDP increases faster than the population, which causes a rise in the GDP per capita (Snowdon \& Vane, 2005). Barro and Sala-i-Martin (2003) presented an interesting calculation and comparison to understand the most important growth factors, especially sustainable long-term growth. The authors made calculations to determine the annual average growth rate for the US economy. They used real per capita GDP by a factor of 10 in 1870 , which equaled $3340 \$$ in 1870 and $33.330 \$$ in 2000 , both on the basis of the 1996 dollar value. They found that the annual growth rate was approximately $1.8 \%$. Emphasizing this point, the authors claimed that if the annual growth rate in the United States (US) was 0.8\% (only $1 \%$ less than the number they found), the per capita GDP in 2000 would only be $9450 \$$ in the US. This growth rate would be similar to the growth rates of countries like Pakistan and India. On the contrary, if the growth rate of the US was $1 \%$ more than the actual value $(2.8 \%)$, then the per capita GDP would be $127.000 \$$, which is 3.8 times more than the actual value in 2000. In fact, no country in recorded history has been able to achieve such a growth rate.

Maddison (2001) answered this question in his studies and noted that world economic growth started to increase considerably around 1820 when the industrial revolution occurred. He stated that changes in factors such as output and population growth level have been unequal over years. There were severe catastrophes in the 6th and 14th centuries, which caused huge slowdowns in economic systems. Also, many countries experienced major recessions in the 17 th century. There were several factors that affected population growth in a very negative way. Among the severest ones were famines, infectious diseases and devastating wars, which continued for hundreds of years. The industrial revolution paved the way for sustainable growth. Starting in the UK, the revolution and resulting economic growth spread across the whole world, but not in an equal way. Significant discrepancies started to emerge among the country's growth rates.

Economic growth has evolved unequally across different regions. North America and Western Europe have managed to achieve high standards of living in comparison to the rest of the World, Japan being an exception. During the latter half of the 20th century, the increase in the difference in income distribution between countries has weakened with rapid economic growth in Asian countries. However, the income gap disparity between the richest and poorest countries (mainly African countries) did not shrink (Evans, 1996). Sala-I-Martin (2006) examined cross country data and reached the conclusion that the proportional income gap inequality among individuals has significantly reduced around the world during the period between 1970 and 2000 .

Relating economic growth and development to external factors rather than internal factors is the main presumption of exogenous growth theories. In neoclassical growth models, an important subject is capital accumulation. Positive output is a consequence of the rise in human capital and augmented labor. One of the main neoclassical growth models is Solow (1956) growth model. According to the Solow model of growth, technological innovation outweighs capital accumulation. Technological innovation is referred to as Total Factor Productivity and is determined exogenously in the model (Pollard, Shackman, \& Piffaut, 2011).

The role of capital in growth theories was strengthened from 1980 onwards. New growth theories started to emphasize the importance of knowledge in achieving growth. New growth theories deal with technological knowledge, its transmission, research and development and the innovation of technologies and consider all these factors to be the main driver of economic growth (Lucas, 1988; Romer, 1990). Early works of Romer and Lucas can be considered as the initial foundations of new endogenous theories, which endogenous technological growth that was considered as an external factor in neoclassical theories. Some of the key studies conducted in the field belong to Romer (1990) and Grossman and Helpman (1994). Howitt claimed that, as innovations are generated by 
Research and Development (R\&D), economic policies fostering competition, property rights etc. can affect R\&D and consequently result in innovation (Howitt, 1999). New growth theories emphasize that economic growth is the result of increasing revenues generated by new knowledge. The ability to develop the economy by increasing knowledge creates opportunities for almost limitless growth. Since ideas can be transmitted and used endlessly, they can be accumulated without restrictions (Cortright, 2001). Governments play an important role in achieving growth in the framework of endogenous growth theories. Government actions such as policies, regulations, institutions and protection of rights can foster growth in the long run (Barro \& Sala-i-Martin, 2003).

Cortright (2001) also noted that, as any kind of physical capital is subject to diminishing returns, sustainable growth based on only physical capital is impossible to achieve. Romer (1986) stated that "we now know that the classical suggestion that we can grow rich by accumulating more and more pieces of physical capital like forklifts is simply wrong."

Economic growth has been extensively researched in the literature from different perspectives. Many studies have focused on the classic determinants of economic growth, such as FDI, trade, unemployment etc. Alfaro, Chanda, Kalemli-Ozcan, and Sayek (2004) focused on the relationship between FDI and economic growth. Belloumi (2014) investigated the trade, FDI and growth nexus in Tunisia. Akeju and Olanipekun (2014) and Kreishan (2011) studied the relationship between unemployment and economic growth. Singh (2010); Zahonogo (2016); El Khoury and Savvides (2006) examined the trade and growth nexus.

Another strand of the literature has focused on economic growth within the framework of endogenous growth theories. Wong, Ho, and Autio (2005) studied the relationship between entrepreneurship, innovation and economic growth. Verspagen (2005) studied innovation and economic growth. The paper of Ulku (2004) focused on R\&D, innovation, and economic growth. Boekema, Morgan, Bakkers, and Rutten (2000) studied the relationship between knowledge, innovation and economic growth.

Last but not least, recent studies have paid significant attention to the connection between environmental issues and economic growth. George, Lin, and Chen (2015) and Mitchell and James (2015) investigated economic growth and circular economies, whereas Smulders (1995); Oyelola, Ajiboshin, Raimi, Raheem, and CN (2013) and Zhang (2012) focused on sustainable economic growth.

\subsection{Economy of China}

Official statistics published by the National Bureau of Statistics of China (NBSC) for the year 2018 revealed many facets of the Chinese economic system. The Chinese population has grown from 962.59 million in 1978 to 1.39 billion in 2017. In 1978, only 172.45 million people lived in cities (urban population), which constituted around $18 \%$ of the total population, but in 2017 , the urbanization rate was recorded to be around $59 \%$. The main reason for this switch can be attributed to better life conditions and employment options developed in urban areas. The annual average growth rate of the total population has been $0.9 \%$. The number of people employed in China reached 776.4 million in 2017. The Gross Domestic Product was 82.71 quadrillion Yuan. Primary Industry contributed 6.54 quadrillion yuan to the GDP, while Secondary Industry contributed 33.46 quadrillion yuan and finally, Tertiary Industry contributed 42.7 quadrillion yuan. Per capita GDP rose from 385 yuan in 1978 to 59,660 yuan in 2017 (China Statistical Yearbook, 2018).

China's stellar economic performance in recent decades cannot simply be interpreted via the neoclassical growth model. New endogenous growth theories can provide more comprehensive modeling of the Chinese economy (Zheng, 2011). Additionally, China's growth strategy changed after the mid-1990s. While China was previously more reliant on capital accumulation in particular, the situation is different now (Zheng \& Hu, 2006). Zheng (2011) suggested that as of the mid-1990s, Chinese economic productivity was a result of policies and reforms and if China cannot maintain its 'reform momentum', productivity and growth will eventually slow down.

Exports have long been an important pillar of economic growth in China. Coates, Horton, and McNamee (2012) claimed that the Chinese kind of growth model has enabled the transmission of new technologies and business know-how to apply to the wider economy, which has generated more productivity gains. However, export-led growth cannot be the main driver of growth forever. Some changes naturally occur such as rising costs of labor. Furthermore, China's large external trade and current account surpluses show that this kind of growth model is unsustainable. To keep the growth rate stable and increasing, Chinese firms will need to pay more attention to innovation and technological progress, especially in high value-added industries. Coates et al. (2012) claimed that shifting the exports strategy is understandable and also a necessary step in economic development. Similar steps were made by other former export intensive emerging economies.

Foreign Direct Investment (FDI) inflow to the country is another major source of growth in China. FDI inflow is generally used in more export-oriented industries such as the electronics industry. FDI inflow has been strongly supported by the government in the last decades. The establishment of special economic zones (SEZ) was an indication of such policies. Due to these policies, many enterprises were founded which were almost completely reliant on foreign investment (Crane, Albrecht, Duffin, \& Albrecht, 2018).

China consists of many regions with discrete characteristics. Discrepancies are visible geographically, socially and economically. From an economic point of view, there is a huge gap in income and living standards among China's urban areas and agricultural areas (Qian \& Smyth, 2008). China's coastal regions are generally urban areas, while the western and central regions are mainly agricultural districts and this divergence can serve as a destabilizing factor for Chinese economy if the gap is too huge (Zhao \& Tong, 2000).

\subsection{The Service Sector}

The standard GB / T 4754, called Industrial Classification for National Economic Activities, defines three levels of industry - Primary, Secondary and "Third industry" or Tertiary industry. Primary industry includes farming, forestry, animal husbandry and fishery industries. Secondary industry includes mining, manufacturing, construction and production and the supply of electric power, gas and water. Finally, the tertiary industry includes traffic, storage and mail businesses, computer service and software industry, wholesale and retail trade, accommodation and food industry, finance industry, scientific research, technical service and geologic examination industry, education, health industry and so on (All China Data, 2017). 
Qin (2006) stated that there has been a significant change in the shares of the three sectors in Chinese economy growth after the reforms were implemented. The share of the agricultural sector in the GDP has decreased from $19.7 \%$ to only $10 \%$. On the other hand, the share of the manufacturing sector has increased from $41.6 \%$ to $46.6 \%$ and the share of the service sector in the GDP has risen from 31.3\% to 434\% between 1990 and 2011.

China is considered as a transformation economy. Wei (1999); Wei (2001) separated China's transition process into three parts, namely decentralization, marketization and globalization. Decentralization refers to the delegation of power from central to local governments and it is a strong indicator of the transition phase (Wei, 2001). Weakening state control on the economy and development of market mechanisms are essential features of the marketization process in China. A decreasing amount of people working in state-owned enterprises is an important indicator of marketization (Zhong \& Wei, 2018). The service sector has been a strong engine of growth in both developed and developing countries. Services are generally characterized by intangibility, heterogeneity, simultaneity of production and consumption, and perishability (Tham, 2017). The World Bank indicates that, in 2014 the share of the service sector in GDP growth rose to $74 \%$ in rich countries. For developing countries, this number constituted $55 \%$ for the same year. However, in China, the share of this sector in GDP is even lower than developing countries, with only $47.8 \%$ in 2014 (Fan, Pan, \& Zhou, 2019). The growth of China's service sector is still behind the global average, particular in relation to the most developed countries (Chan \& Zhao, 2012). Currently, the main service industries in China are financial, consultancy, information and communication, tourism, insurance, education and medical services. China's Ministry of Commerce reported in 2014 that financial services contributed $66.2 \%$ to total services trade from 2012 to 2013 . Consulting and information \& communication sectors came next with $19.9 \%$ and $17 \%$ respectively.

The impact of the service sector on per capita GDP has been researched in different countries. For example, Nayyar (2002) claimed that this sector played a significant role in the economic development of India. The relationship between the service sector and economic growth was a research theme in the studies of Gani and Clemes (2010) where the authors examined the relationship in Pacific Island countries and (Singh, 2010) while the same relationship was examined in India. Anwar and Sam (2008) examined how the service sector impacts economic growth in Singapore. Chen and Whalley (2014) researched trade in services and its contribution to the Chinese economy and concluded that trade in services is growing and is likely to grow further in the next decade.

Previous studies have also examined the real estate and economic growth relationship, which is also empirically examined in this study. Green (1997) showed that housing investment caused growth in GDP in the US, but was not caused by GDP growth, implying that there is a unidirectional causality running from housing investment towards GDP growth. Chau and Zou (2000) researched the short run and long run effects of both public and private housing investments in Hong Kong on GDP and found that an increase in public investment has a positive effect on long run GDP growth, whereas growth in private housing investment affects short run economic output. Liu, Zheng, and Park (2002) used annual time series data and hypothesized that there is a relationship between housing investment and GDP growth. The findings of the research indicated that growth in housing investment positively affects GDP growth in the short run.

\section{Methodology}

China's National Bureau of Statistics regularly publishes Statistical Yearbooks and Yearbooks on specific sectors of the economy or regions. Annual time series data have been used in this study covering the $1990-2018$ time span. For the purpose of the study, data have been collected for three different variables. These variables are Nominal Gross Domestic Product, value added of the hotel and catering industry and value added of the real estate industry between 1990 and 2018. Data have been analyzed in Eviews 10 statistical software. Previously, cointegration tests proposed by Johansen (1991); Engle and Granger (1987); Gregory and Hansen (1996) and Johansen and Juselius (2009) have been widely used in quantitative research. However, these tests require variables to have the same order/rank. Furthermore, these tests have proved to be vulnerable and do not yield precise results when small sample sizes are used. The Bounds Test approach allows these challenges to be overcome, which has increased its popularity among contemporary researchers. The ARDL methodology developed by Pesaran and Shin (1998) will be used in this study. As mentioned above, ARDL methodology does not require the variables to be integrated of the same order and yields effective results in the case of small sample sizes. In this study, the relationship between the overall economic growth and service sector growth of China will be examined. Economic growth is expressed by change in annual nominal GDP (instrumentalized as 100 billion Chinese yuan). The service sector is represented by two subsectors, which are the real estate and the hotel \& catering sectors. Analyzing the overall service sector would be possible as well; however, the sector combines many discrete subsectors and it is better to concentrate on smaller fields inside the sector for more accurate and detailed research. In summary, the value added of the real estate and hotel \& catering sub sectors will be analyzed and the results of the analysis will be implemented to the general service sector.

The research model of the study will be as below:

$$
\text { GDP }=f(\text { REA, HOT })
$$

Transforming Equation 1 into a linear equation, the Equation 2 is obtained:

$$
\mathrm{GDP}_{\mathrm{t}}=\beta_{\mathrm{o}}+\beta_{1} \mathrm{REA}_{\mathrm{t}}+\beta_{2} \mathrm{HOT}_{\mathrm{t}}+\varepsilon_{\mathrm{t}}
$$

$\mathrm{GDP}_{\mathrm{t}}=\beta_{\mathrm{o}}+\beta_{1} \mathrm{REA}_{\mathrm{t}}+\beta_{2} \mathrm{HOT}_{\mathrm{t}}+\varepsilon_{\mathrm{t}} \quad(2)$
Here, GDP $\mathrm{GP}_{\mathrm{t}}$ signifies economic growth at time t, REA $\mathrm{R}_{\mathrm{t}}$ represents value added of the Real Estate sector at time $\mathrm{t}$ and $\mathrm{HOT}_{\mathrm{t}}$ represents the value added of the hotel and catering sector at time $\mathrm{t}$. $\beta_{\mathrm{o}}$ is the constant of the model. $\beta_{1}$ and $\beta_{2}$ are coefficients of variables in the model. Finally, $\varepsilon_{\mathrm{t}}$ is the error term of the model equation.

All variables are transformed into natural logarithms in the model. Therefore, the final version of our model can be presented as Equation 3:

$$
\operatorname{LnGDPt}=\beta_{0}+\beta_{1} \operatorname{LnREA}_{\mathrm{t}}+\beta_{2} \mathrm{LnHOT}_{\mathrm{t}}+\varepsilon_{\mathrm{t}}
$$

The ARDL method requires variables to be stationary at either I(0) or I(1) levels (Im, Pesaran, \& Shin, 2003). According to Narayan and Narayan (2006) it is possible to obtain both short run and long run results using the ARDL Bounds Test Approach. 
The ARDL approach allows us to examine whether there is cointegration among the variables or not. In order to reach a conclusion, the acquired F-statistics needs to be compared with the I(O) lower and I(1) upper critical values obtained by conducting the Bounds Test. If the value of F-statistics is greater than the I(1) upper critical value, we can deduce that there is cointegration among variables. Thus, the null hypothesis can be formulated as 'there is no long run cointegration among the variables' and alternative hypotheses can be expressed as 'there is long run cointegration among the variables'.

Different tests will be used during the empirical analysis of the study. First of all, the stationarity of the variables must be checked. Unit root tests are broadly used to check stationarity. Augmented Dickey-Fuller (ADF) test will be used in this study to check the unit root at both level and the first difference. The ADF test results are presented in Table 1 and Table 2.

Table-1. ADF test results at level.

\begin{tabular}{c|c|c|c|c}
\hline & \multicolumn{6}{|c}{ ADF at level (intercept) } & \multicolumn{2}{c}{ ADF at level (trend and intercept) } \\
\hline Variable & T-Statistic & Prob* & T-Statistic & Prob* $^{*}$ \\
\hline LGDP & $-0,836418$ & 0,7903 & $-4,605173$ & 0,0055 \\
\hline LREA & $-2,304918$ & 0,1774 & $-3,139969$ & 0,1201 \\
\hline LHOT & $-5,917088$ & 0,0000 & $-5,501978$ & 0,0006 \\
\hline
\end{tabular}

Table-2. ADF test results at 1 st difference.

\begin{tabular}{|c|c|c|c|c|}
\hline \multirow[b]{2}{*}{ Variable } & \multicolumn{2}{|c|}{ ADF at 1st Difference (intercept) } & \multicolumn{2}{|c|}{ ADF at 1st Difference (trend and intercept) } \\
\hline & T-statistic & Prob* & T-statistic & Prob* \\
\hline LGDP & $-5,029405$ & 0,0005 & $-4,669908$ & 0,0055 \\
\hline LREA & $-3,814400$ & 0,0076 & $-4,434003$ & 0,0081 \\
\hline LHOT & $-3,933574$ & 0,0057 & $-4,410216$ & 0,0085 \\
\hline
\end{tabular}

The null hypothesis in the ADF test is that LGDP, LHOT and LREA have unit roots at $5 \%$ significance level. The ADF test results show that, although LGDP has a unit root at level (intercept) and LREA also has a unit root at level (intercept and trend \& intercept), none of the variables have a unit root at the 1 st difference. For this reason, it is possible to assert that LGDP and LREA are $\mathrm{I}(1)$ variables, whereas LHOT is an $\mathrm{I}(0)$ variable. This result provides favorable conditions to fulfill the requirements of the ARDL Bounds Test approach.

In the next phase, the long run results derived from the Bounds test will be examined. Table 3 displays the results of the Bounds Test:

Table-3. Bounds test long run results.

\begin{tabular}{c|c|c}
\hline \multicolumn{2}{|c}{ Table-3. Bounds test long run results. } \\
\hline Significance & $\mathbf{I}(\mathbf{0})$ Bound & $\mathbf{I}(\mathbf{1})$ Bound \\
\hline $10 \%$ & 2.63 & 3.35 \\
\hline $5 \%$ & 3.1 & 3.87 \\
\hline $2.5 \%$ & 3.55 & 4.38 \\
\hline $1 \%$ & 4.13 & 5 \\
\hline F-statistic & 11,02723 & \\
\hline
\end{tabular}

According to the rules of the ARDL method, the obtained F-statistics value must be higher than the I(1) upper bound in order to prove co-integration among variables. It is clear that the obtained F-statistics in the model is greater than the upper bound at all significance levels. Thus, it is possible to claim that there is a long run relationship and cointegration among economic growth and value added of the real estate and hotel \& catering sectors. The test also presents numerical values of independent variables in the long run, as indicated in Table 4.

Table-4. Long run coefficients of the independent variables.

\begin{tabular}{|c|c|c|c|c|}
\hline Variable & Coefficient & Std. Error & t-Statistics & Prob. \\
\hline LREA & 0.622930 & 0.042559 & 14.63691 & 0.0000 \\
\hline LHOT & 0.260582 & 0.055512 & 4.694163 & 0.0002 \\
\hline $\mathrm{C}$ & 3.545184 & 0.031014 & 114.3095 & 0.0000 \\
\hline
\end{tabular}

The long run results show that the valued added of both real estate and hotel \& catering subsectors are significant to explain nominal GDP growth. Both the real estate industry and hotel and catering industry positively affect economic growth in the long run. To be more specific, a $1 \%$ increase in the value added of the real estate sub sector will increase nominal GDP by approximately $0.62 \%$ in the long run. At the same time, a $1 \%$ increase in the value added of the hotel and catering sector increases nominal GDP by $0.26 \%$.

The ARDL methodology also makes it possible to check the short run relationship among the variables via the Error Correction Model (ECM). The results obtained from the ECM model are presented in Table 5. Firstly, the short run results indicate the significance of both the independent variables and their lags.

Table-5. Error correction model results.

\begin{tabular}{c|c|c|c|c}
\multicolumn{7}{c}{ Table-5. Error correction model results. } & Prob. \\
\hline Variable & Coefficient & Std. Error & t-Statistics & P.000 \\
\hline $\mathrm{D}(\mathrm{LGDP}(-1))$ & 0.411857 & 0.070328 & 5.856248 & 0.000 \\
\hline $\mathrm{D}(\mathrm{LREA})$ & 0.321199 & 0.040698 & 7.892308 & 0.0000 \\
\hline $\mathrm{D}(\mathrm{LRES}(-1))$ & 0.128055 & 0.047608 & 2.899838 & 0.0095 \\
\hline $\mathrm{D}(\mathrm{LHOT})$ & 0.208239 & 0.057278 & 3.635555 & 0.0019 \\
\hline $\mathrm{D}(\mathrm{LHOT}(-1))$ & -0.233878 & 0.048853 & -4.787345 & 0.0001 \\
\hline CointEq(-1)* & -0.536841 & 0.074836 & -7.173590 & 0.0000 \\
\hline
\end{tabular}


According to Table 5, the coefficient of Real Estate is 0.321199 , which means that a $1 \%$ increase in the value added of the real estate sector increases the country's GDP by around $0.32 \%$. The lag of Real Estate also has a positive and significant impact on the overall GDP of the country. What effect does the hotel and catering sector have on the economic growth of China in the short run? The ECM results show a positive and significant effect of this sector in the short run, with a positive coefficient of 0.208239 . The result implies that a $1 \%$ increase in the value added of the hotel and catering sector will increase GDP by around $0.21 \%$. However, the coefficient of lag of this variable has a negative sign, despite being significant. The coefficient of the Error Correction Model in our model is negative and significant. The ECT coefficient is estimated as -0.536841.

\subsection{Diagnostic Tests}

The Breusch-Pagan-Godfrey test will be used to check whether there is heteroskedasticity in the model. The null hypothesis is that there is no heteroskedasticity in the model and the alternative hypothesis supports the existence of heteroskedasticity in the model. Table 6 shows the heteroskedasticity test results. As the probability value is greater than 0.05 , the null hypothesis cannot be rejected and it can therefore be accepted that there is no heteroskedasticity in the model; in other words, the model is homoscedastic.

Table-6. Breusch-Pagan-Godfrey test results

\begin{tabular}{|c|c|c|c|}
\hline \multicolumn{4}{|c|}{$\begin{array}{l}\text { Heteroscedasticity Test: Breusch-Pagan-Godfrey } \\
\text { Null Hypothesis: Homoscedasticity }\end{array}$} \\
\hline F-statistics & 0.494188 & Prob. $\mathrm{F}(8,18)$ & 0.8446 \\
\hline Obs*R-squared & 4.862303 & Prob. Chi-Square(8) & 0.7722 \\
\hline Scaled explained SS & 1.814528 & Prob. Chi-Square(8) & 0.9862 \\
\hline
\end{tabular}

In order to check serial correlation, the Breusch-Godfrey Serial Correlation LM test will be used in our study. The null hypothesis in this test is that serial correlation is absent in the model. On the contrary, the alternative hypothesis supports that there is serial correlation in our model. The Serial Correlation LM test results are indicated in Table 7.

Table-7. Breusch-Godfrey Serial Correlation LM test results.

Breusch-Godfrey Serial Correlation LM Test
\begin{tabular}{c|c|c|c} 
Null Hypothesis: No serial Correlation at up to 2 lags & Prob. F $(2,16)$ & 0.3171 \\
\hline F-statistic & 1.234895 & Prob. Chi-Square $(2)$ & 0.1644 \\
\hline Obs*R-squared & 3.610454 & & \\
\hline
\end{tabular}

The test results show that the null hypothesis cannot be rejected, as probability value is greater than 0.05 which means there is no autocorrelation in the model up to 2 lags.

Besides the abovementioned diagnostic tests, CUSUM and CUSUM of Squares stability tests were also conducted to check if the model is stable. The CUSUM and CUSUM of Squares test results are indicated in Figure 1 and Figure 2, respectively.
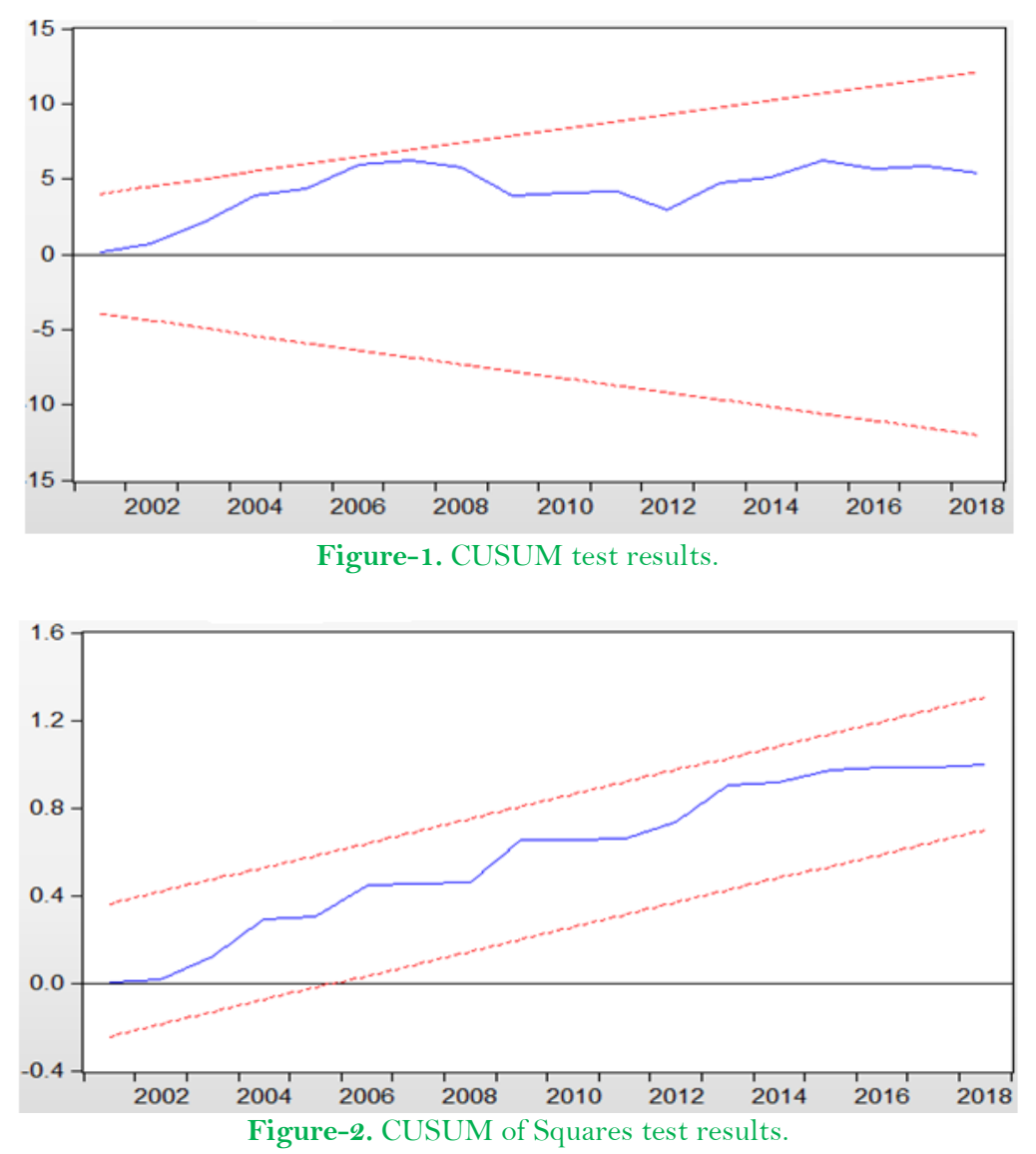

Both test results clearly depict that the model is stable and our results can be used for policy making processes. 


\section{Conclusion and Recommendation}

Time-series data for nominal GDP, value added of real estate sector and value added of hotel and catering sector covering 1990-2018 were collected to conduct this study. Data was analyzed in Eviews 10 Student Version and ARDL methodology was utilized to analyze the collected data. Different methodologies could be used to analyze the data, but ARDL has certain advantages such as providing more precise results for small sample data, the possibility of checking both short run and long run relationships and the ability to use variables integrated of different orders. Different tests were used to strengthen the findings of the data analysis. First of all, the ARDL Bounds Test results showed that nominal GDP in China and value added of real estate and hotel \& catering industries are cointegrated in the long run. This means that there is a long run relationship between nominal GDP growth and growth in value added of the real estate and hotel \& catering industries in China. Furthermore, the value added of the real estate and hotel \& catering subsectors are significant enough to explain nominal GDP growth in China in the long run and finally, both real estate and hotel \& catering subsectors have a positive effect on economic growth in China in the long run. Numerically speaking, a $1 \%$ increase in real estate will increase the GDP by approximately $0.62 \%$ in China in the long run. At the same time, a $1 \%$ increase in the hotel and catering sector increases total GDP by $0.26 \%$. In order to obtain the short run results, the Error Correction Model was used and the results of the ECM showed that value added of real estate and hotel \& catering subsectors are significant to explain nominal GDP growth in China and there is a positive relationship among value added of the real estate, hotel \& catering subsectors and nominal GDP growth in the short run. Numerically, in the short run, a $1 \%$ increase in the value added of the real estate sector increases China's GDP by around $0.32 \%$. The results also imply that an $1 \%$ increase in the value added of the hotel and catering sector will increase China's GDP by around $0.21 \%$ in the short run. The short run and long run results of the research prove that the value added of the two subsectors of the service sector positively and significantly affect the economic growth of China. The findings are in line with those of Green (1997); Chau and Zou (2000) and Liu et al. (2002).

The findings of the data analysis can be generalized and be referred to the overall service sector of China. In other words, the findings prove that the service sector positively affects the economic growth of Chinese economy. The study approves the findings of previous literature on the contribution of the service sector to economic growth, such as studies conducted by Clemes, Hu, and Li (2016) and Nayyar (2002).

The results have practical implications for policymakers in China. Below are our recommendations for policymakers based on the research findings:

i. Further efforts must be made to develop the service sector in China as the development of this sector is still behind the world average level. Further development of the sector will result in a larger contribution to economic growth in the country.

ii. Policies and regulations must be established by the government to eliminate or at least decrease inequality of development among different regions of China. The review of the literature clearly shows that the service sector and overall economic growth is highly regional, which might hinder further growth in China.

iii. Not only real estate and hotel and catering, but also other sub sectors of the services industry should develop. Many subsectors of the service sector in China are highly interconnected and simultaneous growth of various subsectors can promote higher growth of the service sector.

Several suggestions can be made in order to enrich the literature on the theme. First of all, the number of existing studies researching the catering sector in China is very limited and it therefore needs more academic attention. At the same time, trade in services in China requires in-depth analysis. In particular, recent developments in services trade and trade patterns should be intensively researched, as such development might reshape the future of China's economic growth.

\section{Abbreviations:}

ARDL: Autoregressive Distributed Lag Method; ECM: Error Correction Model; FDI: Foreign Direct Investment; HOT: value added of the hotel and catering sector; NBSC: National Bureau of Statistics of China; R\&D: Research and Development; REA: value added of the Real Estate sector.

SEZ: Special Economic Zones; US: United States.

\section{References}

Akeju, K. F., \& Olanipekun, D. B. (2014). Unemployment and economic growth in Nigeria. Journal of Economics and Sustainable Development, $5(4), 138-144$

Alfaro, L., Chanda, A., Kalemli-Ozcan, S., \& Sayek, S. (2004). FDI and economic growth: The role of local financial markets. Journal of International Economics, 64(1), 89-1 12.Available at: https://doi.org/10.1016/s0022-1996(03)00081-3.

All China Data. (2017). Retrieved from: https://www.china-data-online.com/.

Anwar, S., \& Sam, C. Y. (2008). Service sector growth in Singapore. Singapore Management Review, 30(2), 19-33.

Barro, R. J., \& Sala-i-Martin, X. (2003). Economic growth (2nd ed.). Cambridge, Mass: The MIT Press.

Boekema, F., Morgan, K., Bakkers, S., \& Rutten, R. (2000). Knowledge, innovation and economic growth (pp. 137-164). Cheltenham: Edward Elgar Publishing.

Chan, T.-W. G., \& Zhao, S. X. (2012). Advanced producer services industries in Hong Kong and Shenzhen: Struggles towards integration. Asia Pacific Viewpoint, 53(1), 70-85.Available at: 10.1111/j.1467-8373.2012.01476.x.

Chau, K. W., \& Zou, G. (2000). The interaction between economic growth and residential investment. Working Paper, University of Hong Kong, 93-108.

Chen, H., \& Whalley, J. (2014). Chinas service trade. Journal of Economic Surveys, 28(4), 746-774.Available at: 10.1111/joes.12081.

China Statistical Yearbook. (2018). Retrieved from: http://www.stats.gov.cn/tjsj/ndsj/2018/indexeh.htm.

Clemes, M. D., Hu, B., \& Li, X. (2016). Services and economic growth in China: An empirical analysis. Journal of the Asia Pacific Economy, 21(4), 612-627.Available at: 10.1080/13547860.2016.1190492.

Coates, B., Horton, D., \& McNamee, L. (2012). China: prospects for export-driven growth. Retrieved from: https:// treasury.gov.au/publication/economic-roundup-issue-4-2012/china-prospects-for-export-driven-growth.

Cortright, J. (2001). New growth theory, new growth theory, technology and learning: Technology and learning: A practitioner's guide a practitioner's guide. Reviews of Economic Development Literature and Practice, 1(4), 1-40.

Crane, B., Albrecht, C., Duffin, K. M., \& Albrecht, C. (2018). China's special economic zones: An analysis of policy to reduce regional disparities. Regional Studies, Regional Science, 5(1), 98-107.Available at: 10.1080/21681376.2018.1430612. 
El Khoury, A. C., \& Savvides, A. (2006). Openness in services trade and economic growth. Economics Letters, 92(2), $277-283$.

Engle, R. F., \& Granger, C. W. J. (1987). Co-Integration and error correction: representation, Estimation, and testing. Econometrica, 55(2), 251-276.Available at: https://doi.org/10.2307/1913236.

Evans, P. (1996). Using cross-country variances to evaluate growth theories. Journal of Economic Dynamics and Control, 20(6-7), 10271049.Available at: 10.1016/0165-1889(95)00888-8.

Fan, W., Pan, J., \& Zhou, M. (2019). An explanation of the underdevelopment of China's service sector from the perspective of demand. Emerging Markets Finance and Trade, 1-16.Available at: 10.1080/1540496x.2019.1601078.

Gani, A., \& Clemes, M. D. (2010). Services and economic growth in Pacific Island countries. International Journal of Development Issues, 9(2), 113-130.Available at: 10.1108/14468951011062327.

George, D. A., Lin, B. C.-a., \& Chen, Y. (2015). A circular economy model of economic growth. Environmental Modelling \& Software, 73, 6063.

Green, R. K. (1997). Follow the leader: How changes in residential and non-residential investment predict changes in GDP. Real Estate Economics, 25(2), 253-270.Available at: 10.1111/1540-6229.00714.

Gregory, A. W., \& Hansen, B. E. (1996). Residual-based tests for cointegration in models with regime shifts. Journal of Econometrics, 7o(1), 99-126.Available at: https://doi.org/10.1016/0304-4076(69)41685-7.

Grossman, G., \& Helpman, E. (1994). Endogenous innovation in the theory of growth. Journal of Economic Perspectives, 8, 23-44.Available at: $10.3386 / \mathrm{w} 4527$

Howitt, P. (1999). Steady endogenous growth with population and R. \& D. inputs growing. Journal of Political Economy, 107(4), 715730.Available at: $10.1086 / 250076$.

Howitt., P., \& Weil, D. N. (2010). Economic growth. Economic Growth, 38-50.

Im, K. S., Pesaran, M., \& Shin, Y. (2003). Testing for unit roots in heterogeneous panels. Journal of Econometrics, 115(1), 53-74.Available at: $10.1016 /$ s0304-4076(03)00092-7.

Johansen, S. (1991). Estimation and hypothesis testing of cointegration vectors in gaussian vector autoregressive models. Econometrica, 59(6), 1551-1580.Available at: https://doi.org/10.2307/2938278.

Johansen, S., \& Juselius, K. (2009). Maximum likelihood estimation and inference on cointegration - with applications to the demand for money. Oxford Bulletin of Economics and Statistics, 52(2), 169-210.Available at: 10.1111/j.1468-0084.1990.mp52002003.x.

Kreishan, F. M. (2011). Economic growth and unemployment: An empirical analysis. Journal of Social Sciences, 7(2), $228-231$.

Liu, H., Zheng, S., \& Park, Y. W. (2002). The interaction between housing investment and economic growth in China. International Real Estate Review, 5(1), 40-60.

Lucas, R. E. (1988). On the mechanics of economic development. Journal of Monetary Economics, 22(1), 3-42.Available at: 10.1016/03043932(88)90168-7.

Maddison, A. (2001). The world economy: A millennial perspective. Paris: OECD Publications.

Mitchell, P., \& James, K. (2015). Economic growth potential of more circular economies. Banbury, UK: Waste and Resources Action Programme (WRAP).

Narayan, P. K., \& Narayan, S. (2006). Savings behaviour in Fiji: an empirical assessment using the ARDL approach to cointegration. International Journal of Social Economics, 33(7), 468-480.Available at: 10.1108/03068290610673243.

Nayyar, G. (2002). Inside the black box of services: Evidence from India. Cambridge Journal of Economics, 37(1), 143-170.Available at: $10.1093 / \mathrm{cje} / \mathrm{bes} 039$.

Oyelola, O., Ajiboshin, I., Raimi, L., Raheem, S., \& CN, I. (2013). Entrepreneurship for sustainable economic growth in Nigeria. Journal of Sustainable Development Studies, 2(2), 197-215.

Pesaran, M. H., \& Shin, Y. (1998). An autoregressive distributed-lag modelling approach to cointegration analysis. Econometric Society Monographs, 31, 371-413.

Pollard, S. K., Shackman, J. D., \& Piffaut, P. V. (2011). What does the Penn World Table 7.0 tell us about government expenditure and economic growth. International Journal of Economics and Management Sciences, 1(4), 98-111.

Qian, X., \& Smyth, R. (2008). Measuring regional inequality of education in China: Widening coast-inland gap or widening rural-urban gap? Journal of International Development, 20(2), 132-144.Available at: 10.1002/jid.1396.

Qin, D. (2006). Is Chinas growing service sector leading to cost disease? Structural Change and Economic Dynamics, 17(3), 267-287.Available at: 10.1016/j.strueco.2005.09.001.

Romer, P. M. (1986). Increasing returns and long-run growth. Journal of Political Economy, 94(5), 1002-1037.Available at: 10.1086/261420.

Romer, P. (1990). Endogenous technical progress. Journal of Political Economy, 98(5), 71-103.

Sala-I-Martin, X. (2006). The world distribution of income: Falling poverty and ... convergence, period. The Quarterly Journal of Economics, 121(2), 351-397.Available at: 10.1162/qjec.2006.121.2.351.

Singh, T. (2010). Does international trade cause economic growth? A survey. The World Economy, 33(11), 1517-1564.

Singh, T. (2010). Service sector and economic growth in India. Applied Economics, 42(30), 3925-3941.Available at: $10.1080 / 00036840802360229$.

Smulders, S. (1995). Environmental policy and sustainable economic growth. De Economist, 143(2), 163-195.

Snowdon, B., \& Vane, H. R. (2005). Modern macroeconomics. Cheltenham: Edward Elgar Publishing Limited.

Solow, R. M. (1956). A contribution to the theory of economic growth. The Quarterly Journal of Economics, $70(1), 64-65$.
Tham, S. Y. (2017). Examining the shift to services: Malaysia and China compared. Journal of Contemporary Asia, 47(5), 728-751.Available at: 10.1080/00472336.2017.1310273.

Ulku, H. (2004). R\&D, innovation, and economic growth: An empirical analysis. IMF Working Papers, WP/04/185, International Monetary Fund, 2-35.

Verspagen, B. (2005). Innovation and economic growth (pp. 487-513): The Oxford Handbook of Innovation.

Wei, Y. D. (1999). Regional inequality in China. Progress in Human Geography, 23(1), 49-59.Available at: 10.1 191/030913299676254572.

Wei, Y. D. (2001). Decentralization, marketization, and globalization: The triple processes underlying regional development In China. Asian Geographer, 20(1-2), 7-23.Available at: 10.1080/10225706.2001.9684073.

Wong, P. K., Ho, Y. P., \& Autio, E. (2005). Entrepreneurship, innovation and economic growth: Evidence from GEM data. Small Business Economics, 24(3), 335-350.

Zahonogo, P. (2016). Trade and economic growth in developing countries: Evidence from sub-Saharan Africa. Journal of African Trade, 3(12), 41-56.

Zhang, J. (2012). Delivering environmentally sustainable economic growth: The case of China. Asia Society Report, University of California, San Diego, CA, USA, 2-25.

Zhao, X. B., \& Tong, S. P. (2000). Unequal economic development in China: spatial disparities and regional policy reconsideration, $1985-$ 1995. Regional Studies, Regional Science, 34(6), 549-561.

Zheng, J., \& Hu, A. (2006). An empirical analysis of provincial productivity in China (1979-2001). Journal of Chinese Economic and Business Studies, 4(3), 22 1-239.Available at: 10.1080/14765280600991917.

Zheng, J. (2011). Measuring and explaining productivity growth in China. Journal of Chinese Economic and Business Studies, 9(2), 97109.Available at: 10.1080/14765284.2011.568681.

Zhong, Y., \& Wei, D. (2018). Economic transition, urban hierarchy and service industry growth in China. Tijdschrift voor Economische en Sociale Geografie, 109(2), 189-209. 